\title{
Evolution of the clonogenic potential of human epidermal stem/progenitor cells with age
}

This article was published in the following Dove Press journal:

Stem Cells and Cloning:Advances and Applications

28 February 2012

Number of times this article has been viewed

\author{
Olivia Zobiri \\ Nathalie Deshayes \\ Michelle Rathman-Josserand \\ Department of Biological Research, \\ L'Oréal Advanced Research, Clichy \\ Cedex, France
}

\begin{abstract}
A number of clinical observations have indicated that the regenerative potential and overall function of the epidermis is modified with age. The epidermis becomes thinner, repairs itself less efficiently after wounding, and presents modified barrier function recovery. In addition, the dermal papillae flatten out with increasing age, suggesting a modification in the interaction between epidermal and dermal compartments. As the epidermal regenerative capacity is dependent upon stem and progenitor cell function, it is naturally of interest to identify and understand age-related changes in these particular keratinocyte populations. Previous studies have indicated that the number of stem cells does not decrease with age in mouse models but little solid evidence is currently available concerning human skin. The objective of this study was to evaluate the clonogenic potential of keratinocyte populations isolated from the epidermis of over 50 human donors ranging from 18 to 71 years old. The data indicate that the number of epidermal cells presenting high regenerative potential does not dramatically decline with age in human skin. The authors believe that changes in the microenvironment controlling epidermal basal cell activity are more likely to explain the differences in epidermal function observed with increasing age.
\end{abstract}

Keywords: skin, epidermal stem cells, aging, colony-forming efficiency test

\section{Introduction}

The skin, and more specifically the epidermis, is one of the most active human tissues in terms of regeneration. This particular compartment of the skin turns over approximately every 28 days, a regenerative process maintained by resident keratinocyte populations located in the basal layer, including stem cells and their progeny, the progenitor cells (transient amplifying cells). Epidermal regeneration is tightly controlled by various micro-environmental factors including stem and progenitor cell interactions with the basement membrane, neighboring cells, and paracrine factors secreted by the dermal compartment. Observations of age-related changes in the epidermis, including epidermal thinning and decreasing numbers of proliferative cells, ${ }^{1,2}$ modifications in the structure and composition of the epidermal-dermal junction, ${ }^{3-5}$ and a decrease in the efficiency of wound healing, ${ }^{6}$ suggest a modification in the functionality of the stem and progenitor cell population over time. Epidermal aging could be explained by a decrease in the number or receptivity of the regenerative cells residing in the tissue and/or by modifications in the micro-environment controlling their activity. A number of recent studies in mice have indicated that the number and intrinsic potential of epidermal stem cells does not change according to submit your manuscript | www.dovepress.com

Dovepress

http://dx.doi.org// 0.2147//SCCAA.S28355
Stem Cells and Cloning: Advances and Applications 20I2:5 I-4

(C) 2012 Zobiri et al, publisher and licensee Dove Medical Press Ltd. This is an Open Access article which permits unrestricted noncommercial use, provided the original work is properly cited. 


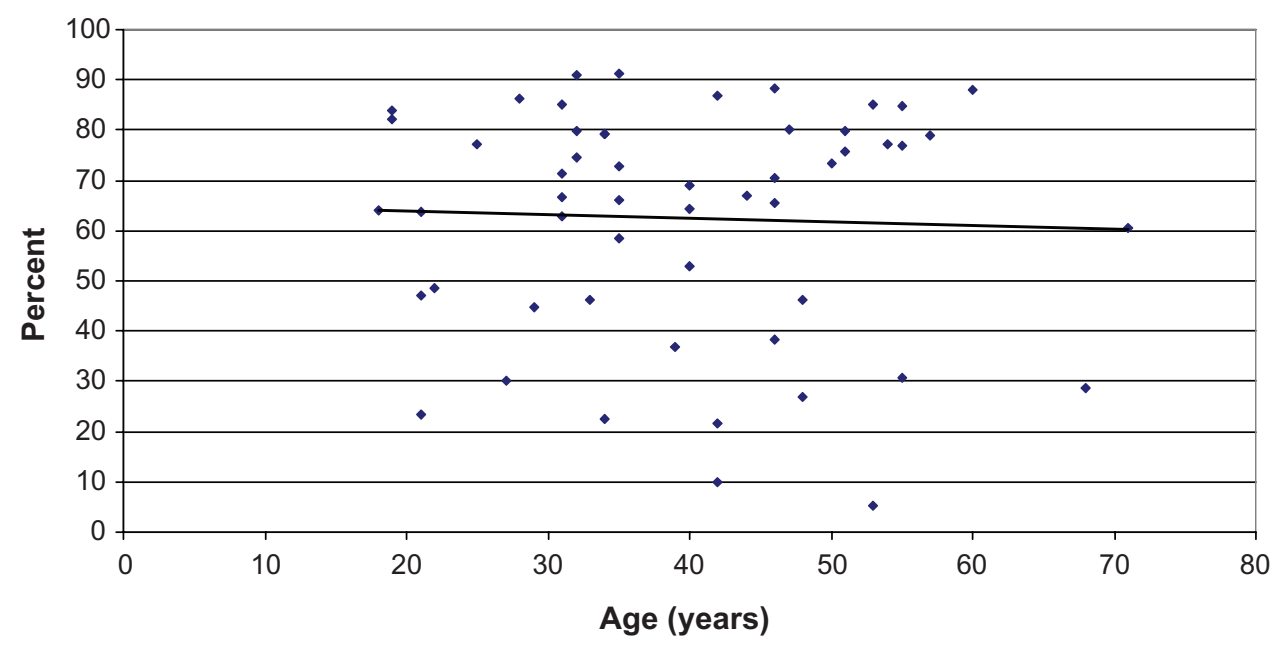

Figure I Graphical representation of the clonogenic potential as a function of donor age: results reported as the percentage of the petri dish surface occupied by clones. Notes: Each point represents the average of biological triplicates for one single donor. The linear regression line indicates the global tendency.

the age of the animal..$^{7-9}$ Data from Charruyer and colleagues suggest that slower wound healing in aged mice is not due to a decline in stem cell potential but rather the decreasing proliferative output of progenitor cells. ${ }^{7}$

Studies of stem cells are inherently more difficult to perform when examining human skin. The inability to apply modern genetic tools and difficulties in obtaining human biological material limit the type of experimentation that can be performed. Nevertheless, attempts have been made to increase our knowledge of human skin stem cell reservoirs. Two different, often cited publications suggest that human epidermal stem cell numbers diminish with age. ${ }^{10,11}$ As these studies were performed on no more than four donors with only one or two donors representing each age group analyzed, the present study undertook a broader analysis of human keratinocyte clonogenic potential.

\section{Methods and results}

This analysis was performed using the Clone Forming Efficiency test (a modified version of the protocol originally developed by Barrandon and Green). ${ }^{9}$ The Clone Forming Efficiency test is used to quantify the frequency of cells capable of generating a sufficient number of progenitors to form a cell colony, within a given keratinocyte population. It is considered that a strong clonogenic potential is characteristic of stem and early progenitor cells,

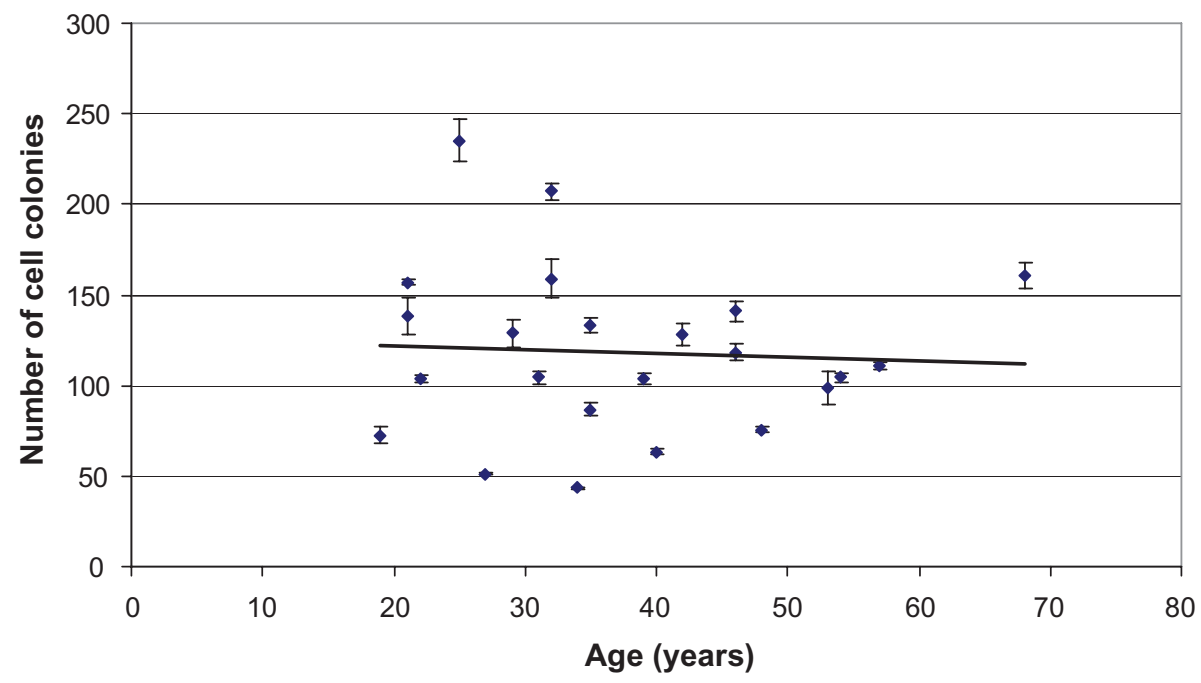

Figure 2 Graphical representation of the clonogenic potential as a function of donor age: results reported as the number of cell colonies (manual counts). Notes: Each point represents the average of biological triplicates for one single donor. The linear regression line indicates the global tendency. 
while differentiated keratinocytes lose this clone-forming potential. ${ }^{10}$

The study presented here was conducted on 53 skin samples derived from breast tissue of healthy donors undergoing esthetic surgery. After extraction of the total keratinocyte population, a cell fraction highly enriched in stem and progenitor cells was selected based on the capacity of such cells to adhere very quickly to an extracellular matrix. ${ }^{12-14}$ This method, although not specific for stem cells, has been previously been demonstrated to reproducibly isolate a keratinocyte population with high clonogenic potential, extensive long term growth capacity (exceeding 100 cell doublings) and the ability to generate a pluristratified epidermis. Transcriptomic profiling studies have additionally shown a strong similarity of this population with the cell population selected for high surface expression of integrin $\alpha 6$, a marker often associated with epithelial stem cells. ${ }^{14}$ The cells were then resuspended in a DMEM Hams F12 medium (3:1 mixture) containing $2 \mathrm{mM}$ L-glutamine and $1 \mathrm{mM}$ sodium pyruvate (all from Gibco-Life Technologies SAS) and supplemented with 10 fetal calf serum (HyClone-Fisher Scientific SAS, Illkirch, France), nonessential amino acids (Gibco-Life Technologies SAS, Saint Aubin, France), $5 \mathrm{mg} / \mathrm{ml}$ insulin, $0.18 \mathrm{mM}$ adenine, $0.4 \mathrm{mg} / \mathrm{mL}$ hydrocortisone, $2 \mathrm{~nm}$ tri-iodothyronine (all from Sigma-Aldrich Chimie S.a.r.l, Lyon, France), $10 \mathrm{ng} / \mathrm{mL}$ epidermal growth factor (Chemicon, Temecula, CA), $1 \mathrm{mM}$ isoproterenol (Sigma-Aldrich Chimie S.a.r.l), $5 \mathrm{mg} / \mathrm{mL}$ transferin (Sigma-Aldrich Chimie S.a.r.l), $4 \mathrm{mM}$ glutamine (Gibco-Life Technologies SAS), and $50 \mathrm{U} / \mathrm{mL}$ penicillin/streptomycin (Gibco-Life Technologies SAS) and seeded at very low densities (1000 cells per Petri dish) on a feeder-layer of irradiated 3T3 fibroblasts. The medium was changed at day 3 and day 8 and the experiment was stopped at day 10. At the end of this culture period, the resulting clones (cell colonies) were fixed with $70 \%$ ethanol for 10 minutes, colored (3-5 minutes incubation with Eosin-RAL 555 [Réactifs RAL, Martillac, France] wash and then 3-5 minutes incubation with Blue-RAL 555 [Réactifs RAL]), and quantified. Quantification of the clonogenic potential was performed by calculating the percentage of the surface area occupied by the cell colonies using ImageJ software (v 1.4.3.67). The results reported represent an average of three petri dishes per experimental condition (ie, per donor) (Figure 1). The mathematical average and standard error (standard deviation divided by the square root of the sample size) were calculated for each sample
$(\mathrm{N}=53)$. When possible, a direct count of cell colonies was also performed (Figure 2). Such an analysis was only performed on samples for which distinct cell colonies could be clearly distinguished $(\mathrm{N}=23)$.

\section{Discussion and conclusion}

The results presented here indicate that the clonogenic potential of human keratinocyte cell populations highly enriched in stem/progenitor cell fractions does not dramatically diminish with age. Direct counts of colony numbers confirm that the number of epidermal stem and progenitor cells demonstrating a clonogenic potential remains largely intact throughout aging. The methods used do not allow a direct quantification of the epidermal stem cell reservoir but these data suggest that the stem and progenitor cell pool appears largely intact even as epidermal regeneration and function is clearly modified with age. This observation would suggest that, in vivo, the keratinocyte pool does not continue to fully express its full potential/proliferative capacity. The authors hypothesize that epidermal aging is thus more a function of altered micro-environmental signaling as opposed to loss of cell numbers. Indeed, modification of micro-environmental cues controlling a number of different stem cell reservoirs has been recently highlighted in age-related changes in other regenerative tissues, notably in muscle. ${ }^{15}$ Studies more specifically focused on skin aging have revealed that the quality of the basement membrane and overall structure of the epidermal-dermal junction, important components of the microenvironment controlling stem and progenitor cell function, are indeed modified. ${ }^{3-5}$ In addition, the fibroblast population juxtaposed to the epidermis (dermal papillary fibroblasts), has been demonstrated to undergo differences in protein secretion activity as a function of age. ${ }^{16} \mathrm{As}$ dermal fibroblasts certainly play a very important role in controlling keratinocyte activity via the secretion of paracrine factors, this type of modification could also explain the observed differences in aged epidermises.

\section{Disclosure}

The authors report no conflicts of interest in this work.

\section{References}

1. Gilhar A, Ullmann Y, Karry R, et al. Ageing of human epidermis: the role of apoptosis, Fas and telomerase. Br J Dermatol. 2004;150(1): 56-63.

2. Gambichler T, Matip R, Moussa G, Altmeyer P, Hoffmann K. In vivo data of epidermal thickness evaluated by optical coherence tomography: effects of age, gender, skin type and anatomic site. J Dermatol Sci. 2006;44(3):145-152. 
3. Lavker RM. Structural alteration in exposed and unexposed aged skin. J Invest Dermatol. 1979;73(1):59-66.

4. Lavker RM, Zheng P, Dong G. Aged skin: a study by light, transmission, electron and scanning electron microscopy. Aged Skin. 1987;88(3): $44 \mathrm{~S}-50 \mathrm{~S}$.

5. Vazquez F, Palacios S, Aleman N, Guerrero F. Changes of the basement membrane and type IV collagen in human skin during aging. Maturitas. 1996;25:209-215.

6. Wicke C, Bachinger A, Coerper S, Beckert S, Witte MB, Königsrainer A. Aging influences wound healing in patients with chronic lower extremity wounds treated in a specialized Wound Care Center. Wound Repair Regen. 2009;17(1):25-33.

7. Charruyer A, Barland CO, Yue L, et al. Transit-amplifying cell frequency and cell cycle kinetics are altered in aged epidermis. J Invest Dermatol. 2009;129(11):2574-2583.

8. Giangreco A, Qin M, Pintar JE, Watt FM. Epidermal stem cells are retained in vivo throughout skin aging. Aging Cell. 2008;7(2):250-259.

9. Stern MM, Bickenbach JR. Epidermal stem cells are resistant to cellular aging. Aging Cell. 2007;6(4):439-452.

10. Barrandon Y, Green H. Three clonal types of keratinocyte with different capacities for multiplication. Proc Natl Acad Sci U S A. 1987;84(8): 2302-2306.
11. Youn SW, Kim DS, Cho HJ, et al. Cellular senescence induced loss of stem cell proportion in the skin in vitro. J Dermatol Sci. 2004;35(2): $113-123$.

12. Jones PH, Watt FM. Separation of human epidermal stem cells from transit amplifying cells on the basis of differences in integrin function and expression. Cell. 1993;73(4):713-724.

13. Kim DS, Cho HJ, Choi HR, Kwon SB, Park KC. Isolation of human epidermal stem cells by adherence and the reconstruction of skin equivalents. Cell Mol Life Sci. 2004;61(21):2774-2781.

14. Fortunel NO, Chadli L, Bourreau E, et al. Cellular adhesion on collagen: a simple method to select human basal keratinocytes which preserves their high growth capacity. Eur J Dermatol. 2011;21(2): 12S-20S.

15. Carlson ME, Conboy IM. Loss of stem cell regenerative capacity within aged niches. Aging Cell. 2007;6(3):371-382.

16. Mine S, Fortunel NO, Pageon H, Asselineau D. Aging alters functionally human dermal papillary fibroblasts but not reticular fibroblasts: a new view of skin morphogenesis and aging. PLoS One. 2008; 3(12): 4066.
Stem Cells and Cloning: Advances and Applications

\section{Publish your work in this journal}

Stem Cells and Cloning: Advances and Applications is an international, peer-reviewed, open access journal. Areas of interest in stem cell research include: Embryonic stem cells; Adult stem cells; Blastocysts; Cordblood stem cells; Stem cell transformation and culture; Therapeutic cloning; Umbilical cord blood and bone marrow cells; Laboratory,

\section{Dovepress}

animal and human therapeutic studies; Philosophical and ethical issues related to stem cell research. This journal is indexed on CAS. The manuscript management system is completely online and includes a quick and fair peer-review system. Visit http://www.dovepress.com/ testimonials.php to read real quotes from published authors. 